\title{
Importance and Genetic Diversity of Vegetable-Infecting Tospoviruses in India
}

\author{
Suresh R. Kunkalikar, Sudarsana Poojari, Bhanupriya M. Arun, Prem A. Rajagopalan, \\ Tsung-Chi Chen, Shyi-Dong Yeh, Rayapati A. Naidu, Usha B. Zehr, and Kankanallu S. Ravi
}

First, second, third, fourth, eighth, and ninth authors: Plant-Virus Interactions Lab, Mahyco Research Center, Dawalwadi, Post Box no. 76, Jalna, Maharashtra, 431203, India; fifth and sixth authors: Department of Plant Pathology, National Chung Hsing University, Taichung, Taiwan, R.O.C.; and second and seventh authors: Department of Plant Pathology, Irrigated Agriculture Research and Extension Center, Washington State University, Prosser 99350. First and second authors contributed equally to this work. Accepted for publication 7 October 2010.

\begin{abstract}
Kunkalikar, S. R., Poojari, S., Arun, B. M., Rajagopalan, P. A., Chen, T.-C., Yeh, S.-D., Naidu, R. A., Zehr, U. B., and Ravi, K. S. 2011. Importance and genetic diversity of vegetable-infecting tospoviruses in India. Phytopathology 101:367-376.

A survey for Peanut bud necrosis virus (PBNV), Watermelon bud necrosis virus (WBNV), Capsicum chlorosis virus (CaCV), and Iris yellow spot virus (IYSV) was conducted between 2002 and 2009 in the major vegetable-growing areas in India. PBNV was documented widely in tomato and chili peppers in 14 states representing southern, north-

regions. In addition, the expanded host range of PBNV to watermelons and other cucurbits and WBNV to tomato and chili peppers was observed leading to natural mixed infection of the two viruses. IYSV was found in onion in southern, central, and north-eastern regions and $\mathrm{CaCV}$ in tomato and chili peppers in northern and southern regions, respectively. Phylogenetic analysis of the nucleocapsid gene revealed segregation of field isolates of PBNV and WBNV into two distinct subclades, whereas isolates of $\mathrm{CaCV}$ and IYSV each clustered into a single clade. A proposal for establishing WBNV as a distinct tospovirus species is made based on the molecular characterization of small- (S) and medium- (M) RNA segments.
\end{abstract} western, north-eastern, and central regions and WBNV was predominantly detected in watermelons and cucurbits in all except north-eastern
Additional keyword: sero-diagnosis.
India is the world's second largest producer of vegetables with an annual production of 87.53 million tonnes from 5.86 million hectares representing $14.4 \%$ to the world production (FAO statistics, 2009). A variety of vegetables are grown under field conditions in the diverse agroclimatic zones of the country making it possible to grow almost all varieties of fresh vegetables year round to meet the increased demand for dietary requirements of vegetables in both rural and urban areas. In India, tomato, chili pepper, okra, potato, and onion are economically important and occupy nearly $50 \%$ of the total area under vegetable production. Chili pepper, onion, and tomato are cultivated in an area of 9.3, 4.54 , and 0.35 million ha with a production of 8.0, 6.3, and 5.3 million metric tons, respectively, and contribute significantly to India's agricultural exports.

Diseases caused by tospoviruses (family Bunyaviridae; genus Tospovirus) are emerging as a significant limiting factor for the sustainable production of vegetables in India. To date, Peanut bud necrosis virus (PBNV) (10,32), Peanut yellow spot virus (PYSV) (31), Watermelon bud necrosis virus (WBNV) (14), Iris yellow spot virus (IYSV) (25), and Capsicum chlorosis virus (CaCV) $(18,19)$ have been identified in the country. PBNV, CaCV, and IYSV represent definitive members and PYSV and WBNV are considered tentative species of the genus Tospovirus (7). PBNV, WBNV, CaCV, and IYSV have been detected in different vegetables, whereas the natural host range of PYSV is currently not known. In recent years, the geographical expansion of PBNV,

Corresponding author: K. S. Ravi; E-mail address: ravi.kankanallu@mahyco.com

* The $\boldsymbol{e}$-Xtra logo stands for "electronic extra" and indicates that Figure 3 appears in color online.

doi:10.1094/PHYTO-02-10-0046

(C) 2011 The American Phytopathological Society
WBNV, CaCV, and IYSV have been reported in the country due to increased area of production of different vegetable crops. However, reliable information regarding the distribution of these four tospoviruses in different vegetable-growing regions is lacking.

Until the mid-2000, the occurrence of PBNV was limited to a few regions. Beginning in 2001, epidemics of PBNV were reported in several tomato-growing regions of India, including Hoskote and Nasik regions of Karnataka and Maharashtra States, respectively, that are the major tomato-producing areas. Consequently, PBNV has become a major constraint $(1,26)$, there by limiting the sustainability of tomato that contributes nearly $8 \%$ of the total production of vegetables in India (www.indiabudget. nic.in). Meanwhile, 90 to $100 \%$ incidence of tospovirus infections in chili peppers has caused significant concern to farmers in Khammam and Warangal districts of Andhra Pradesh State (26). Currently, PBNV is recognized as the most wide spread and damaging tospovirus in India, causing production problems to both legumes and solanaceous crops (38).

WBNV is an economically important pathogen of watermelon [Citrullus lanatus (Thumb.) Matsun and Nakai], with the disease incidence in some areas reaching $100 \%$ leading to total loss of watermelons. The virus has also been reported in ridge gourd (Luffa acutangula Roxb.) (20), cucumber (Cucumis sativus L.) (13), and bitter gourd (Momordica charantia L.). In 2005, an IYSV epidemic was reported in major bulb and seed onions in Maharashtra state (25). IYSV has a direct bearing on the export potential of onions because India ranks second in global onion production and onion is the fourth most important commercial vegetable crop, accounting for 5\% share in the vegetable production. $\mathrm{CaCV}$ was reported for the first time in tomato in northern India during 2007 post-rainy season (December to May) and subsequently in chili peppers in southern India (17-19). Previ- 
ously, $\mathrm{CaCV}$ was reported in chili pepper in Australia $(15,21)$, tomato in Thailand $(4,16)$, and peanut in China (2). PYSV is considered of less economic importance to vegetables as its incidence is sporadic and confined to peanut.

Different tospoviruses are known to produce similar, though not identical, symptoms in a given crop making symptoms-based diagnosis difficult (36). Therefore, an understanding of the prevalence and genetic diversity of natural populations of tospoviruses will help in developing sustainable disease management strategies. This is especially critical due to the lack of genetic sources of resistance to PBNV and WBNV in vegetables. In this study, samples were collected from vegetable crops suspected for tospovirus infection from major vegetable-growing regions of India between 2002 and 2009 and tested for PBNV, WBNV, CaCV, and IYSV using virus-specific diagnostic assays. In addition, sequence analysis of the nucleocapsid gene of field isolates revealed diversity among these viruses with isolates of PBNV and WBNV segregating into two distinct subclades and isolates of $\mathrm{CaCV}$ and IYSV each forming a single clade. The results also revealed an expanded host range of PBNV and WBNV that may facilitate their natural mixed infections in tomatoes and watermelons. A proposal for establishing WBNV as a distinct tospovirus species is made based on the molecular characterization of small- $(\mathrm{S})$ and medium- (M) RNA segments.

\section{MATERIALS AND METHODS}

Collection of samples. Samples were obtained from surveys conducted between 2002 and 2009 during rainy (June to November) and post-rainy (December to May) cropping seasons in major vegetable growing regions of India. A total of 914 plant samples suspected for tospovirus infection were collected from southern (Andhra Pradesh [AP], Karnataka [KAR], Tamil Nadu [TN], and Goa [GOA]), north-western (Gujarat [GUJ], Rajasthan [RAJ] and Delhi [DEL], north-eastern (Chattisgarh [CHA], Uttar Pradesh [UP], Haryana [HAR], West Bengal [WB]), and central (Maharashtra [MAH], and Madhya Pradesh [MP]) states of India (Fig. 1).

Serological testing of samples. The samples were tested for PBNV, WBNV, and CaCV by direct antigen coating-enzymelinked immunosorbent assay (DAC-ELISA) using polyclonal antibodies (PAbs) to the $\mathrm{N}$ protein of PBNV isolate infecting peanut (obtained from the International Crops Research Institute for the Semi-Arid Tropics, Hyderabad, India). Onion samples were tested

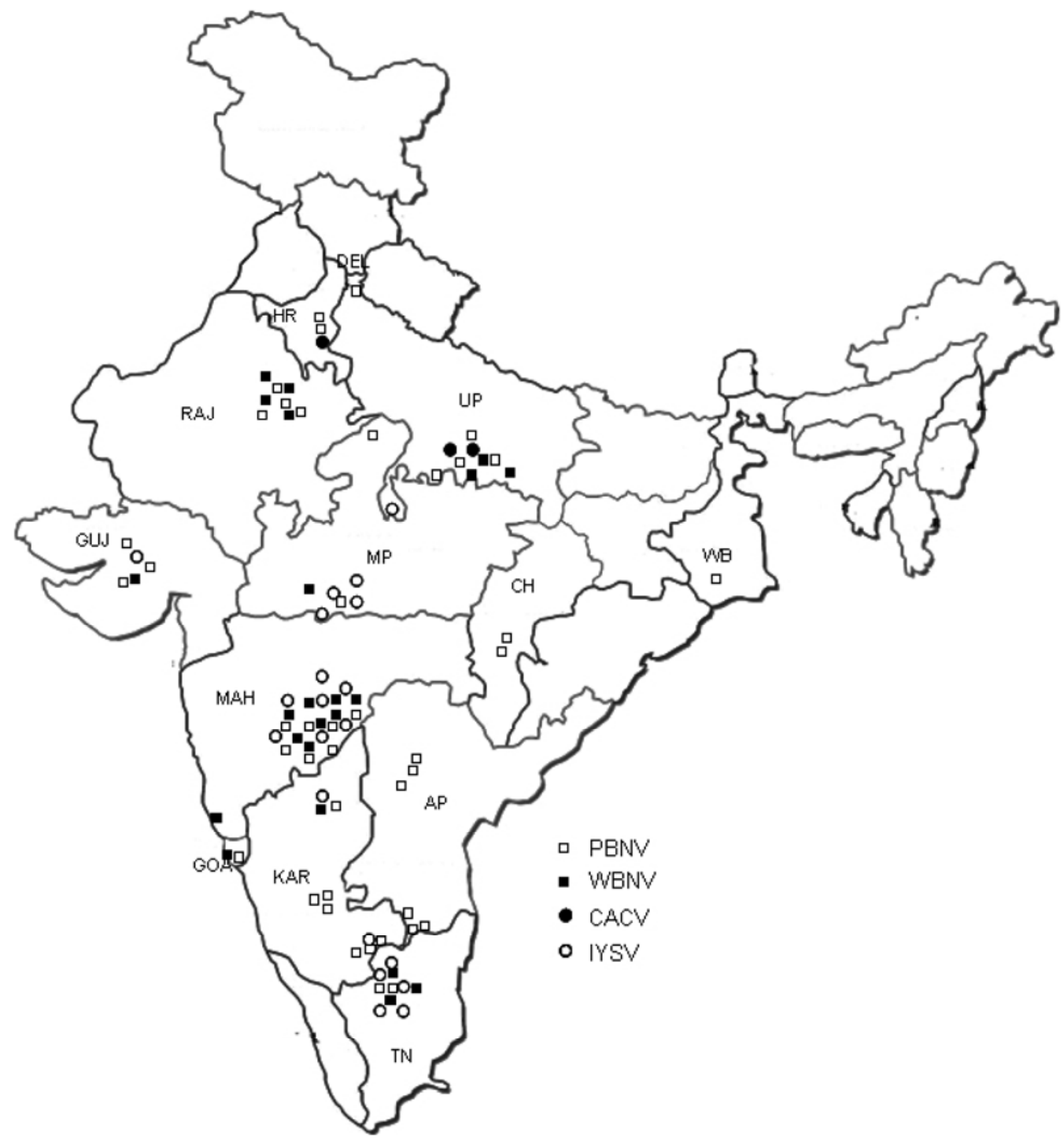

Fig. 1. Geographical map of India indicating locations from where vegetable-infecting tospoviruses viz. Peanut bud necrosis virus (PBNV), Watermelon bud necrosis virus (WBNV), Capsicum chlorosis virus (CaCV), and Iris yellow spot virus (IYSV) samples were collected: 76 isolates of PBNV ( $\square$ ), 28 isolates of WBNV (ם), 3 isolates of $\mathrm{CaCV}(\bullet)$, and 28 isolates of IYSV(O) were characterized for the $\mathrm{N}$ gene sequence. The locations of the isolates are marked: APAndhra Pradesh, KAR-Karnataka, TN-Tamil Nadu, GJ-Gujrat, GOA-Goa, RAJ-Rajasthan, DEL-Delhi, CH-Chattisgarh, UP-Uttar Pradesh, WB-West Bengal, MAH-Maharashtra, and MP-Madhya Pradesh. 
by double antibody sandwich-ELISA (DAS-ELISA) using polyclonal antibodies to the $\mathrm{N}$ protein of IYSV (obtained from Deutsche Sammlung von Mikroorganismen und Zellkulturen GmbH [DSMZ], Germany). In addition, samples were tested using PAbs raised against the $\mathrm{N}$ protein of Watermelon silver mottle virus (WSMoV), Tomato spotted wilt virus (TSWV), IYSV, Tomato yellow fruit ring virus (TYFRV), and CaCV (obtained from DSMZ, Germany). Monoclonal antibodies (MAbs) specific to $\mathrm{N}$ and nonstructural protein (NSs) of PBNV and WSMoV were also used to test samples by triple antibody sandwich-ELISA (TAS-ELISA) (3) (Table 1). Absorbance values at $405_{\mathrm{nm}}$ that were threefold or more higher than the negative control were considered to be positive.

Cloning and sequencing of $\mathbf{N}$ gene. Total RNA was extracted from ELISA-positive samples of representative virus isolates using the RNeasy Plant Mini kit (Qiagen Inc., Chatsworth, CA). Fifty nanograms of total RNA was used as template in reverse transcription-polymerase chain reaction (RT-PCR) assay consisting of $1 \times$ AMV/Tfl buffer, $2.5 \mu \mathrm{M}$ each of dNTPs, $2 \mathrm{mM} \mathrm{MgSO}_{4}$, 10 picomoles of each primer, $2.5 \mathrm{U}$ of AMV reverse transcriptase and $2.5 \mathrm{U}$ Tfl DNA polymerase in a $25 \mu \mathrm{l}$ reaction volume (Access RT-PCR kit, Promega Corp., Madison, WI). A pair of degenerate primers (Mh-F and Mh-R) was designed based on the $\mathrm{N}$ gene sequence of PBNV, WBNV, CaCV, and WSMoV available in GenBank and used to amplify the $\mathrm{N}$ gene sequence (Table 2). RT-PCR was carried out in GeneAmp 9700 PCR machine (Applied Biosystems) at $42^{\circ} \mathrm{C}$ for $45 \mathrm{~min}$ followed by denaturation at $94^{\circ} \mathrm{C}$ for $3 \mathrm{~min}$, and 35 cycles of PCR with each cycle consisting of $94^{\circ} \mathrm{C}$ for $1 \mathrm{~min}, 57^{\circ} \mathrm{C}$ for $45 \mathrm{~s}$ and $72^{\circ} \mathrm{C}$ for $1 \mathrm{~min}$. Final extension was carried out at $72^{\circ} \mathrm{C}$ for $10 \mathrm{~min}$. The amplified products were cloned into pGEM-T Easy vector (Promega Crop.) following the manufacturer's instructions and sequenced using BigDye terminator cycle sequencing kit (Applied Biosystems) using an automated DNA sequencing system (3130 Genetic Analyzer-Applied Biosystems) (29). Two independent clones for each isolate were sequenced in both orientations by using universal M13 reverse and forward primers.

Cloning and sequencing of S- and M-RNA of WBNV. An isolate of WBNV (WBNV-Wm-Jal) collected from a watermelon field near Jalna, Maharastra State, was used for cloning and sequencing of S- and M-RNA segments. A single lesion isolate obtained after two successive inoculations on Chenopodium quinoa was inoculated onto $N$. benthamiana and viral doublestranded RNA (dsRNA) extracted as described by Yeh et al. (39). The dsRNA was subsequently used as template for amplification of S- and M-RNA segments by RT-PCR. Forward and reverse primers to amplify S-RNA were designed based on the conserved nucleotide (nt) sequences in the S-RNA of PBNV (NC_003619, AY871098), WSMoV (NC_003843, AY864852), and CaCV (NC_008301, DQ256123). Primers for amplifying the M-RNA segment of WBNV were designed based on the conserved nucleotide (nt) sequences in the M-RNA of PBNV (NC_003620,
AY871097), WSMoV (NC_003841), and CaCV (NC_008303). The primer sequences and their location in the S- and M-RNA of WBNV are listed in Table 2. RT-PCR was carried out in a GeneAmp 9700 PCR machine (Applied Biosystems) with 1 cycle for cDNA synthesis at $42^{\circ} \mathrm{C}$ for $45 \mathrm{~min}$ followed by 35 cycles of PCR with each cycle consisting of $94^{\circ} \mathrm{C}$ for $30 \mathrm{~s}, 55^{\circ} \mathrm{C}$ for $45 \mathrm{~s}$, and $72^{\circ} \mathrm{C}$ for $90 \mathrm{~s}$ and a final extension step at $72^{\circ} \mathrm{C}$ for $15 \mathrm{~min}$. Cloning and sequencing of the amplified fragments was carried out as described above.

Sequence analysis. Nucleotide sequences were analyzed using the Contig-Express and AlignX tools available in Vector NTI software version 6.0 (Invitrogen). Amino acid sequences were deduced from the primary nt sequence data either by using the same software or using translation program in Bio-Edit Sequence

TABLE 2. Nucleotide sequences of forward and reverse primers used for polymerase chain reaction to amplify $\mathrm{N}$ gene of Peanut bud necrosis virus (PBNV-R), Capsicum chlorosis virus (CaCV-R), and M RNA of Watermelon bud necrosis virus (WBNV-R)

\begin{tabular}{llc}
\hline Primer name & \multicolumn{1}{c}{ Sequence } & Position \\
\hline $\mathrm{N}$ gene & & \\
Mh-F & ATGTCTAMCGTYARGCAACTTAC & - \\
Mh-R & CCCTYACAMTTCHAKAGAWGDRCTAG & - \\
PBNV-R & GGGTTGCTTTCACTCAATAGCTT & - \\
WBNV-R & CCATAGTCATCCATGGAAAGA & - \\
CaCV-R & CATAACATCATCCTGAGAGCACATG & -
\end{tabular}

$S$ and M RNA of WBNV

S RNA

AGAGCAATCGGGGCATCTAA

SN1-R

SN2-F TACGCAAAAACTGTTG

AGATGAGAATCAACGT

$1-20^{\mathrm{a}}$

SN2-R GCCTCTTTCGAGGTC

SN3-F ATGAAAGTTAATAAAG

SN3-R GACTATGGTGAGCATCC

SN4-F TTACACTTCCAGAGAAG

SN4-R ATGTCTAACGTTAAGCAAC

SN5-F GCTGAGCAACTCAACAGCTG

SN5-R AGAGCAATCGAGGCGC

M RNA

SM1-F

AGAGCAATCGGTGCGCCAATTA

SM1-R TCACGAATTTCCAAGTAAGTTAT

SM2-F GAAGCTTACAAAAGGTTGCAGA

SM2-R TATAGAGTCTATGGAATCTAATG

SM3-F CTAGATGTCTAAAGAGAAATCATAA

SM3-R TTGTACAAACATATATGATCTATC

SM4-F GCAGATCTCTGCCGACACATGAC

SM4-R ATCAATTCTCATCTCATATATACC

SM5-F CCAAACTTATCAGTTGTCAGAT

SM5-R GTACTGTGTCATTAAAGGTGT

908-924

$1651-1637$

1584-1599

2567-2551

2511-2519

3338-3319

2666-2686

3405-3390

SM6-F

TATGTTTGAAGAGCTGCTTATGC

1-22

983-961

880-901

1517-1495

1409-1433

2624-2601

2546-2568

3512-3489

3399-3420

4493-4473

${ }^{a}$ Nucleotide positions correspond to the S and M RNA of WBNV-Wm-Jal isolate (EU249351, FJ694963).

TABLE 1. Serological cross reaction of Peanut bud necrosis virus (PBNV), Watermelon bud necrosis virus (WBNV), Capsicum chlorosis virus (CaCV), and Iris yellow spot virus (IYSV) to antisera in enzyme-linked immunosorbent assay

\begin{tabular}{|c|c|c|c|c|c|c|c|c|}
\hline \multirow[b]{2}{*}{ Sl no. } & \multirow[b]{2}{*}{ Antisera $^{a}$} & \multicolumn{7}{|c|}{ Absorbance $\left(\mathrm{A}_{450 \mathrm{~nm}}\right)$} \\
\hline & & PBNV-To-Hsk & WBNV-Wm-Jal & CaCV-To-Var & IYSV-On-Nas & Healthy tomato & Healthy watermelon & Healthy onion \\
\hline 1 & PBNV-NP PAb & 1.852 & 1.625 & 0.895 & 0.095 & 0.121 & 0.095 & 0.092 \\
\hline 2 & PBNV-NP MAb & 0.995 & 0.979 & 0.458 & 0.085 & 0.115 & 0.090 & 0.089 \\
\hline 4 & WSMoV-NSs MAb & 1.578 & 0.531 & 0.528 & 0.082 & 0.112 & 0.085 & 0.083 \\
\hline 5 & CaCV-NP PAb & 0.381 & 0.319 & 0.985 & 0.153 & 0.130 & 0.152 & 0.119 \\
\hline 6 & IYSV-NP PAbs & 0.103 & 0.115 & 0.118 & 0.945 & 0.121 & 0.114 & 0.112 \\
\hline
\end{tabular}

a WSMoV, Watermelon silver mottle virus; TYFRV, Tomato yellow fruit ring virus; TSWV, Tomato spotted wilt virus; and PYSV, Peanut yellow spot virus. 

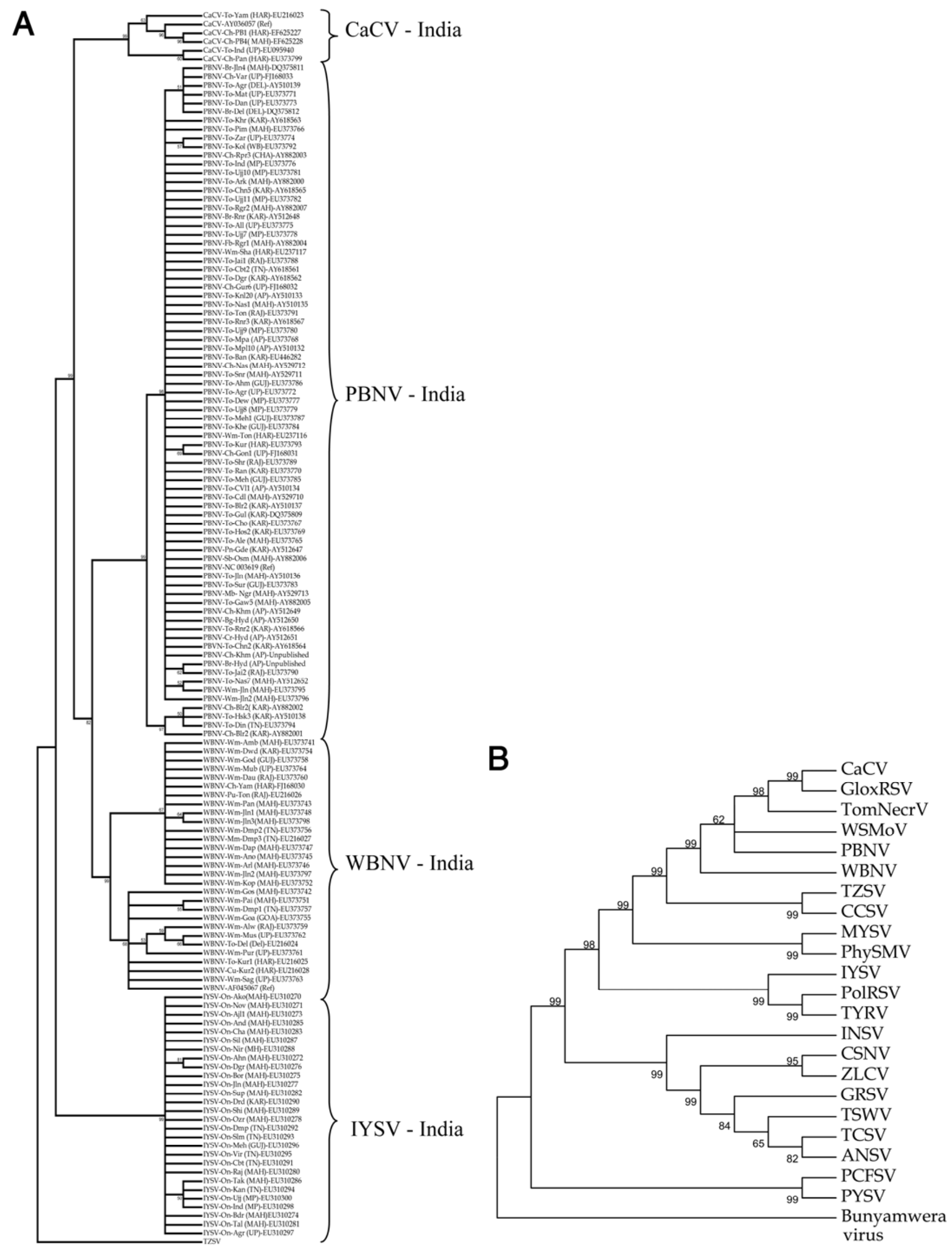
Editor (version 7.2) and then compared with corresponding sequences available in GenBank. Multiple sequence alignments were generated by ClustalW and sequence identities determined using Bio-Edit Sequence Editor. Phylogenetic trees were constructed by N-J method using MEGA 3.1 (34) and with 1,000 bootstrap replications.

Multiplex RT-PCR. Multiplex RT-PCR was carried to detect $\mathrm{CaCV}, \mathrm{PBNV}$, and WBNV in mixed virus infections. Degenerate forward primer (Mh-F) and species-specific reverse primer (PBNV-R, WBNV-R, and CaCV-R) were designed to amplify 494, 647-, and 764-bp fragment specific to CaCV, PBNV, and WBNV, respectively (Table 2). The conditions for multiplex RTPCR included RT for $45 \mathrm{~min}$ at $42^{\circ} \mathrm{C}$ followed by 35 cycles of PCR $\left(30 \mathrm{~s}\right.$ at $94^{\circ} \mathrm{C}, 45 \mathrm{~s}$ at $57^{\circ} \mathrm{C}$, and $1 \mathrm{~min}$ at $\left.72^{\circ} \mathrm{C}\right)$ and $10 \mathrm{~min}$ extension at $72^{\circ} \mathrm{C}$.

\section{RESULTS}

Serological detection of PBNV, WBNV, CaCV, and IYSV. A panel of PAbs and MAbs produced against different tospoviruses for their ability to detect PBNV, WBNV, CaCV, and IYSV was tested. The results (Table 1) showed that samples infected with PBNV, WBNV, and CaCV gave higher $\mathrm{A}_{405}$ values (>1.5) with MAbs raised against the $\mathrm{N}$ protein of WSMoV indicating a common epitope present in the $\mathrm{N}$ protein of these tospoviruses. Conversely, both PAbs and MAbs raised against the $\mathrm{N}$ protein of PBNV gave higher $\mathrm{A}_{405}$ values with WBNV- but not $\mathrm{CaCV}$ infected samples, indicating that WBNV is serologically more closely related to $\mathrm{PBNV}$ than to $\mathrm{CaCV}$. The PBNV samples gave higher $\mathrm{A}_{405}$ values with a MAb raised against the NSs protein of WSMoV, whereas WBNV- and CaCV-infected samples gave lower $\mathrm{A}_{405}$ values indicating that PBNV and WSMoV shared common epitopes in their NSs protein. In contrast, PAbs raised against the $\mathrm{N}$ protein of $\mathrm{CaCV}$ gave lower $\mathrm{A}_{405}$ values with $\mathrm{PBNV}$ and WBNV infected samples further indicating that $\mathrm{CaCV}$ is serologically distantly related to both PBNV and WBNV. The onion samples infected with IYSV gave positive $\mathrm{A}_{405}$ values with PAbs to the $\mathrm{N}$ gene of IYSV and negative results with antibodies to $\mathrm{PBNV}, \mathrm{CaCV}$, and WSMoV. None of the samples tested positive with antibodies specific to TSWV and TYFRV. Based on these results, we selected PAbs and MAbs raised against the $\mathrm{N}$ protein of PBNV and WSMoV, respectively, for documenting PBNV, WBNV, and $\mathrm{CaCV}$ in different vegetables and PAbs raised against the $\mathrm{N}$ protein of IYSV for testing onion samples collected from disease surveys.

Multiplex reverse transcription-polymerase chain reaction. Due to serological cross-reactions mentioned a multiplex reverse transcription-polymerase chain reaction (RT-PCR) was optimized for the detection of $\mathrm{CaCV}, \mathrm{PBNV}$, and WBNV using a degenerate upstream primer (Mh-F) and species-specific downstream reverse primers (PBNV-R, WBNV-R, and CaCV-R). The 494-, 647-, and 764-bp fragments specific to $\mathrm{CaCV}$, PBNV, and WBNV, respectively, were amplified in single and mixed virus infections. The specificity of virus-specific amplicons was ascertained by cloning and sequencing and comparing with corresponding sequences of PBNV, WBNV, and CaCV (data not shown).
Distribution and incidence of PBNV, WBNV, CaCV, and IYSV. A combination of ELISA and RT-PCR was used to detect PBNV, WBNV, CaCV, and IYSV in samples collected during surveys conducted over a period of 8 years between 2002 and 2009.

PBNV was detected in 650 samples collected from vegetable crops tomato, chili pepper, brinjal, and carrot from the southern (TN, KAR, AP, and GOA), central (MAH and MP), north-western (GUJ and RAJ), and north (UP, HAR, DEL, and CH) and northeastern (WB) states of India (Fig. 1). Nearly $40 \%$ of these samples came from tomato fields. PBNV was found at a low incidence in eggplant (Solanum melongena L.) in MAH, KAR, AP, and DEL states, chili pepper in MAH, KAR, AP, UP, and $\mathrm{CH}$ states, fababean, mungbean, and soybean in MAH, pumpkin in KAR and blackgram in AP, watermelon in MAH and HAR states, and carrot in AP state. The incidence of PBNV in different tomato cultivars and hybrids grown in farmers' fields in different locations was highly variable, ranging from 1 to $85 \%$. Severe outbreaks of PBNV were observed in the Nasik region of MAH (80\% incidence) during 2004, Hoskote, Bangalore, and Ranebennur regions of KAR (90 to $95 \%$ incidence) in 2006, and Madanapalli and Khammam regions of AP (90 to $100 \%$ incidence) in 2003 and 2006. A broad range of disease symptoms such as chlorotic, necrotic spots on leaves, and necrotic streaks on petioles, stems, and buds were observed. Chlorotic concentric rings, yellow blotches and reduced fruit size were commonly observed in several varieties and hybrids (Fig. 2). No definite correlation was observed between symptoms in different cultivars/ hybrids, seasons and/or geographic locations. During winter (December to March) cropping in northern India, bronzing of the canopy was one of the dominant symptoms of PBNV in tomato. These results indicated widespread distribution of PBNV in vegetables with higher level of incidence in tomato.

The incidence of WBNV was up to $90 \%$ in watermelon fields in MH, KAR, RAJ, and UP states of India (Fig. 1). About 54 leaf and stem samples from symptomatic watermelons tested positive in DAC-ELISA with PAbs specific to the $\mathrm{N}$ protein of PBNV, since previous studies have shown that PAbs to PBNV can detect WBNV (27). In 2004, high incidence (up to 80\%) was recorded in Jalna district of MAH, $70 \%$ incidence in Dharwad district of $\mathrm{KAR}$, and $55 \%$ in Dharmapuri district of TN states. However, variation in symptoms on watermelon leaves, stem and fruits was observed in different locations. The predominant symptoms include mosaic, mottling, necrotic spots on leaves, necrosis of lateral and flower buds; necrotic spots and streaks on stem, upward bending of growing tips of infected plants, and shortened internodes leading to stunted growth. Early-infected plants produced no or small fruits, while late infection resulted in the production of malformed fruits with chlorotic and/or necrotic spots and/or rings on fruit surface (Fig. 3).

$\mathrm{CaCV}$ was observed in symptomatic tomato and chili pepper collected from Indian states of Haryana and Uttar Pradesh in 2008. However, the incidence of $\mathrm{CaCV}$ was low when compared with the incidence of PBNV. Infected tomato produced necrotic rings on leaves and chlorotic lesions on fruits, whereas chili pepper and bell pepper produced chlorotic to necrotic rings on leaves and yellow blotches on fruits with reduced size (Fig. 3).

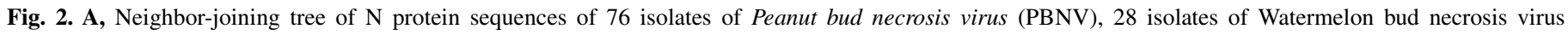

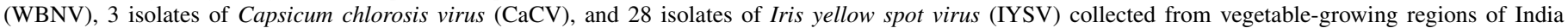

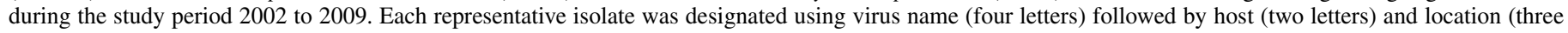

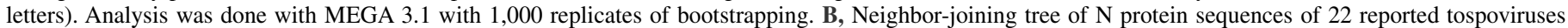

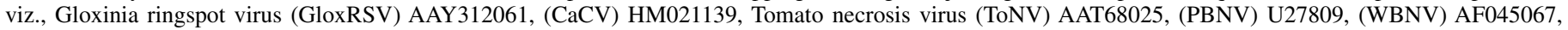

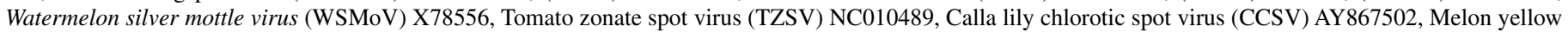

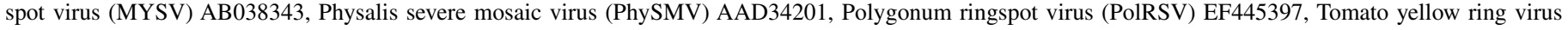

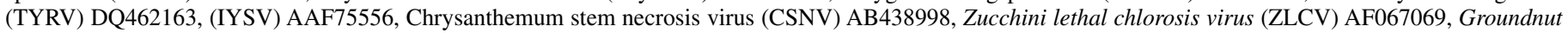

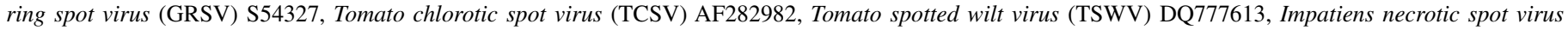

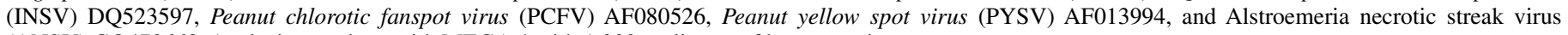
(ANSV) GQ478668. Analysis was done with MEGA 4 with 1,000 replicates of bootstrapping. 
These symptoms were similar to those produced by PBNV making it difficult to differentiate $\mathrm{CaCV}$ from PBNV under field conditions based on symptoms.

Onion samples suspected for IYSV infection were collected from 17 districts in MAH, KAR, TN, GUJ, UP, and MP states. Virus-infected plants showed a wide range of symptoms, consisting of chlorotic spindle-shaped lesions, chlorotic spindleshaped concentric rings, long yellow stripes, and bending of scapes. Among these symptoms, spindle shaped lesions were predominant in most of the samples. Since 2008, symptoms with yellow stripes running from top to bottom of scapes were also observed in samples collected from GUJ and MAH states. In many cases, two to three types of symptoms were observed on a single plant (Fig. 3). The disease was more prominent on seed crop than the bulb crop. The disease incidence varied from 50 to $85 \%$ in different locations, with Nasik district of MAH state recording $85 \%$ incidence.
Expanded host range of WBNV to cucurbit and solanaceous crops. A muskmelon (Cucumis melo L.) field in Dharmapuri district of TN was observed with $45 \%$ disease incidence and leaves of infected plants showed mosaic mottling and necrosis. In DAC-ELISA, symptomatic leaves tested positive with PAbs to the $\mathrm{N}$ protein of PBNV. In order to confirm whether the virus was PBNV or WBNV, the N gene was amplified by RT-PCR, cloned, and sequenced. A comparison of the $\mathrm{N}$ gene sequence with corresponding sequences of other tospoviruses revealed 93.5 and 96.3\% identity at nucleotide and amino acid level, respectively, with the N gene of WBNV. Similarly, presence of WBNV in a pumpkin field showing $40 \%$ disease incidence in Tonk district of RAJ state and in a cucumber field showing $25 \%$ incidence in Kurukshetra district of HAR state was confirmed by $\mathrm{N}$ gene sequence analysis. In these fields, pumpkin and cucumber were grown as intercrop with watermelon. In 2007, plants in eight tomato and three chili pepper fields in Kurukshetra district of
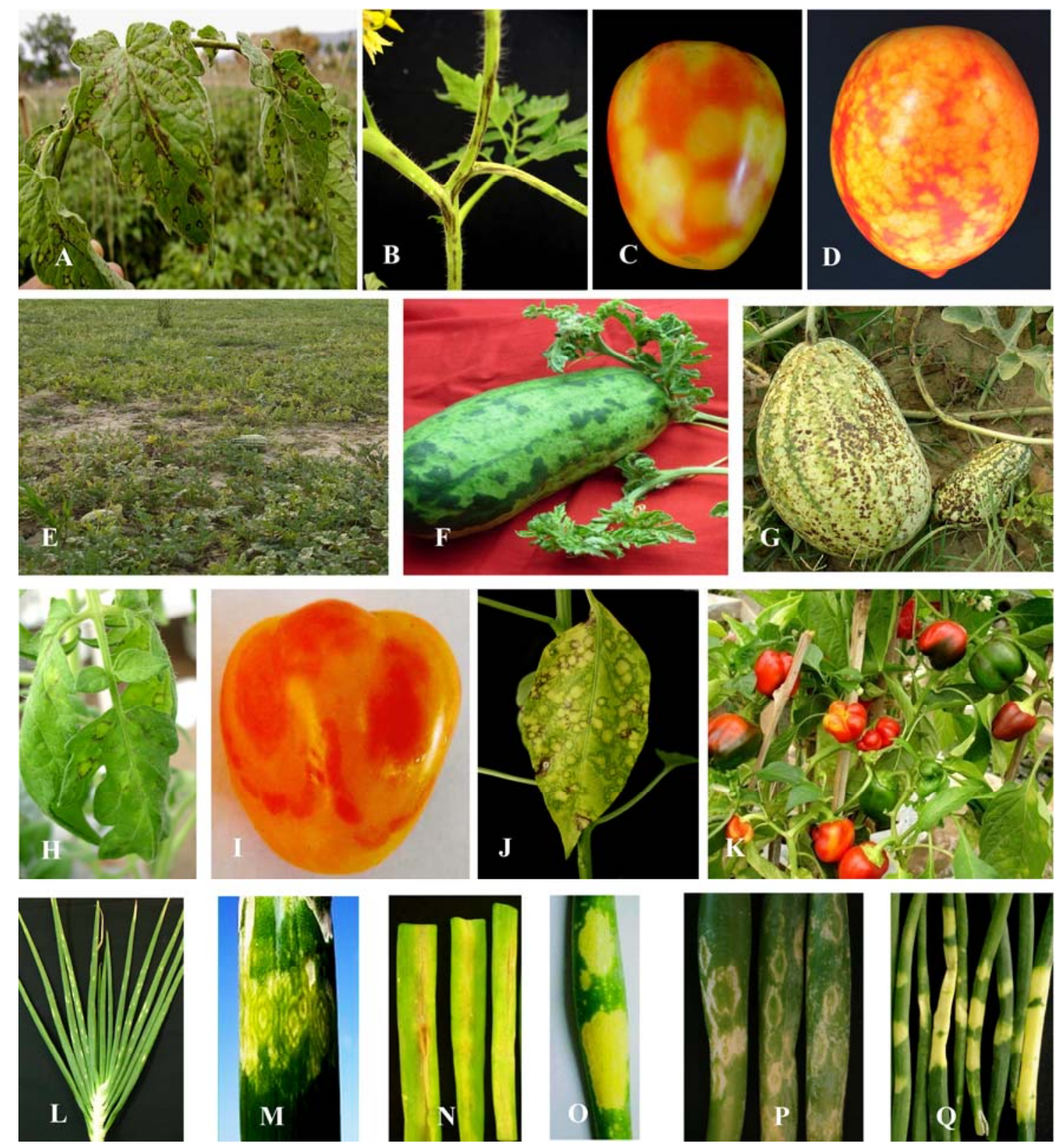

Fig. 3. Peanut bud necrosis virus symptoms; $\mathbf{A}$, necrotic spots/rings on leaves; $\mathbf{B}$, necrotic streaks on petiole; $\mathbf{C}$, chlorotic spots on fruit; and $\mathbf{D}$, chlorotic blotches on fruit. Watermelon bud necrosis virus symptoms: $\mathbf{E}$, chlorosis and upward curling of plants; $\mathbf{F}$, chlorotic lesions on fruit; and $\mathbf{G}$, necrotic spots and reduced size of fruits. Capsicum chlorosis virus symptoms: $\mathbf{H}$, necrotic rings on tomato leaf; $\mathbf{I}$, chlorotic rings on tomato; $\mathbf{J}$, chlorotic and necrotic rings on leaf; and $\mathbf{K}$, reduced size of bell pepper fruits with blotches. Iris yellow spots virus symptoms: L, chlorotic lesions on infected plan; $\mathbf{M}$, chlorotic rings on spathe; $\mathbf{N}$, chlorotic stripes on spathe; and $\mathbf{O}, \mathbf{P}$, and $\mathbf{Q}$, oval/spindle shaped elongated lesions on spathe. 
Haryana state and northern part of Delhi showed symptoms resembling those caused by tospovirus infection. These samples tested positive to PAbs against the $\mathrm{N}$ protein of PBNV in DACELISA and the $\mathrm{N}$ gene of isolates from tomato (WBNV-To-Del, WBNV-To-Har) and chili pepper (WBNV-Ch-Pan) revealed 93.5 to $93.9 \%$ and 97.8 to $98.1 \%$ identity, respectively, with WBNV N gene sequences. These results indicated expanded host range of WBNV under field conditions to different cucurbit and solanaceous crops. To our knowledge, this is the first report of the occurrence of WBNV in tomato and chili pepper.

Mixed infections of PBNV and WBNV. During a survey of watermelon fields in Jalna area of MAH state in June 2006, severe mosaic mottling on leaves, necrotic streaks on stem, petiole and growing buds, and chlorotic and/or necrotic rings on malformed fruits was observed in two watermelon fields. Samples from two individual plants were tested positive for both PBNV and WBNV in multiplex RT-PCR assay (data not shown). To ascertain their specificity to each virus, the amplicons were cloned and four independent clones were sequenced. Nucleotide sequences from two clones shared 97.8 to $97.9 \%$ and $98.9 \%$ identity at the nucleotide and amino acid level, respectively, with PBNV (NC_003619, AY871098) and the other two clones shared 92.8 to $93.8 \%$ and 96.0 to $96.3 \%$ identity at nucleotide and amino acid level, respectively, with WBNV (EU373795 to 98). These results indicated presence of PBNV and WBNV sequences in a single plant and, to our knowledge, this is the first report of natural mixed infection of PBNV and WBNV in watermelons.

Sequence diversity and phylogenetic clustering. The nucleotide sequence of the $\mathrm{N}$ gene of 76 field isolates of PBNV, 28 field isolates of WBNV and 28 field isolates of IYSV was determined (Table 3). In pairwise comparisons, the $76 \mathrm{~N}$ gene sequences of PBNV showed identities ranging between 91.3 and $100 \%$ at the amino acid level. The identities among WBNV $\mathrm{N}$ gene sequences ranged between 94.1 and $100 \%$, among $\mathrm{CaCV} \mathrm{N}$ gene sequences ranged between 97.0 and $98.9 \%$, and IYSV N gene sequences ranged between 94.8 and $100 \%$ at the amino acid level. These values are within the limits of species demarcation criteria for members of the genus Tospovirus, where isolates with $90 \%$ or more amino acid sequence similarity are considered strains of the same virus (7). Based on these results, it can be concluded that divergent strains of PBNV, WBNV, CaCV, and IYSV are present in different vegetable crops in India. The $\mathrm{N}$ gene-based phylogenetic relationships of PBNV, WBNV, and IYSV isolates were compared among themselves and with corresponding sequences available in GenBank. The results (Fig. 2A) showed segregation of PBNV, WBNV, and $\mathrm{CaCV}$ each into two clades, with greater number of $\mathrm{PBNV}$ and $\mathrm{CaCV}$ sequences clustering within one clade and WBNV isolates segregating more or less equally between two clades. The mean genetic distances between PBNV, WBNV, and CaCV clades are 0.161, 0.170, and 0.222, respectively. In contrast, IYSV sequences formed a monophyletic cluster single lineage. These results may indicate propensity of the occurrence of distinct variants of PBNV, WBNV, and CaCV, but not IYSV, in India. The $\mathrm{N}$ gene-based phylogenetic relationships of PBNV, WBNV, and IYSV isolates were compared among themselves and with other tospovirus sequences available in GenBank (Fig. 2B).

Molecular characterization of S- and M-RNA of WBNV. The full-length S-RNA segment of WBNV-Wm-Jal isolate consisted of 3,405 nts with two open reading frames (ORFs) in ambisense arrangement. The first ORF (67 to 1,386 nts) encoded the NSs protein with a predicted $\mathrm{Mr}$ of $49.6 \mathrm{kDa}$ in sense direction, whereas the second ORF (2,511 to 3,339 nts) encoded $\mathrm{N}$ protein with a predicted $\mathrm{Mr}$ of $30 \mathrm{kDa}$ in antisense direction. The $\mathrm{A} / \mathrm{T}$ rich intergenic region consisted of 1,124 nts. The $5^{\prime}$ and $3^{\prime}$ untranslated regions (UTRs) consisted of 66 and 67 nts, respectively, with high potential to form a genomic panhandle pseudocircle.

The sequence identity of WBNV-Wm-Jal isolate with other tospoviruses is shown in Table 4. The intergenic region combining NSs and $\mathrm{N}$ genes was 351 nts longer than PBNV S-RNA and 131 nts shorter than WSMoV (NC_003843) and CaCV (FJ011449) S-RNAs. Structural analysis of S-RNA using

TABLE 3. Comparison of $\mathrm{N}$ gene amino acid identity of tospoviruses

\begin{tabular}{|c|c|c|c|c|c|c|}
\hline \multirow[b]{2}{*}{ Sl. no } & \multirow[b]{2}{*}{ Tospovirus $^{\mathrm{a}}$} & \multirow[b]{2}{*}{ Amino acids } & \multicolumn{4}{|c|}{$\mathrm{N}$ gene amino acid identity $(\%)$} \\
\hline & & & PBNV (this study) & WBNV (this study) & $\mathrm{CaCV}$ (this study) & IYSV (this study) \\
\hline 1 & PBNV (this study) & 276 & $91.3-100$ & - & - & - \\
\hline 2 & WBNV (this study) & 275 & $81.1-86.2$ & $94.1-100$ & - & - \\
\hline 3 & CaCV (this study) & 275 & $82.2-86.2$ & $78.5-82.1$ & $97.0-98.9$ & - \\
\hline 4 & IYSV (this study) & 273 & $42.2-45.5$ & $41.5-44.0$ & $44.0-45.5$ & $94.8-100$ \\
\hline 5 & PBNV-NC_003619 & 276 & 98.9 & 85.5 & 85.1 & 44.8 \\
\hline 6 & WBNV-AF045067 & 275 & 84.4 & 97.0 & 81.8 & 43.0 \\
\hline 7 & CaCV-AY036057 & 275 & 83.6 & 78.9 & 96.7 & 45.1 \\
\hline 8 & CaCV-EF625227 & 275 & 83.6 & 79.2 & 97.0 & 45.1 \\
\hline 9 & CaCV-EF625228 & 275 & 83.6 & 79.2 & 97.0 & 45.1 \\
\hline 10 & IYSV-DQ838590 & 273 & 43.7 & 42.2 & 43.3 & 90.8 \\
\hline 11 & IYSV-DQ150107 & 273 & 44.0 & 42.6 & 43.7 & 90.8 \\
\hline 12 & IYSV-AF067070 & 273 & 43.7 & 42.6 & 43.3 & 90.8 \\
\hline 13 & IYSV-DQ233478 & 273 & 43.7 & 42.2 & 43.3 & 90.4 \\
\hline 14 & WSMoV-AY514629 & 275 & 84.7 & 82.1 & 84.3 & 43.3 \\
\hline 15 & MYSV-AY673635 & 279 & 58.0 & 57.3 & 56.9 & 48.2 \\
\hline 16 & TYFRV-DQ810195 & 274 & 43.0 & 41.9 & 43.3 & 73.3 \\
\hline 17 & TYFRV-DQ788694 & 274 & 42.6 & 41.9 & 43.0 & 72.9 \\
\hline 18 & ZLCV-AF067069 & 260 & 27.8 & 26.8 & 28.3 & 28.1 \\
\hline 19 & GRSV-AF251271 & 258 & 28.5 & 28.3 & 29.7 & 30.2 \\
\hline 20 & TCSV-AF282982 & 258 & 27.1 & 26.8 & 28.6 & 29.1 \\
\hline 21 & TSWV-DQ777470 & 258 & 27.8 & 27.5 & 29.7 & 30.9 \\
\hline 22 & INSV-DQ523598 & 262 & 26.8 & 25.8 & 28.0 & 26.0 \\
\hline 23 & PCFSV-AF080526 & 270 & 20.5 & 19.1 & 20.9 & 18.1 \\
\hline 24 & PYSV-AY529714 & 246 & 18.2 & 18.2 & 21.1 & 18.7 \\
\hline 25 & TZSV-NC_010489 & 278 & 62.5 & 62.5 & 61.1 & 43.4 \\
\hline
\end{tabular}

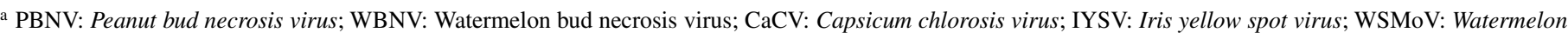
silver mottle virus; MYSV: Melon yellow spot virus; TYFRV: Tomato yellow fruit ring virus; ZLCV: Zucchini lethal chlorosis virus; GRSV: Groundnut ring spot virus; TCSV: Tomato chlorotic spot virus; TSWV: Tomato spotted wilt virus; INSV: Impatiens necrotic spot virus; PCFV: Peanut chlorotic fan spot virus; PYSV: Peanut yellow spot virus; and TZSV: Tomato zonate spot virus. 
NetNGlyc site indicated the potential to form two hairpin structures as reported in WSMoV. The nucleotide sequence comparison of $3^{\prime}$ and $5^{\prime}$ UTRs revealed that $46 \%$ of nucleotides are complementary to each other, which is less compared with $85 \%$ identity with WSMoV (NC_003843) and 80\% with TSWV (D13926). The terminal $7 \mathrm{nts}$ of $5^{\prime}$ UTR were complementary to 7 nts of 3' UTR.

The M-RNA segment of WBNV-Wm-Jal isolate consisted of 4,794 nts with two ORFs in ambisense arrangement similar to other tospoviruses. The ORF (55 to 975 nts) encoded the putative NSm protein with a predicted $\mathrm{Mr}$ of $34.1 \mathrm{kDa}$ in sense direction and the second ORF (1,388 to 4,750 nts) encoded $\mathrm{Gn} / \mathrm{Gc}$ protein with a predicted $\mathrm{Mr}$ of $127.5 \mathrm{kDa}$ in antisense direction. The $\mathrm{A} / \mathrm{T}$ rich intergenic region combining $\mathrm{NSm}$ and $\mathrm{Gn} / \mathrm{Gc}$ consisted of 412 nts. The $5^{\prime}$ and $3^{\prime}$ UTRs consisted of 54 to $44 \mathrm{nts}$, respectively, with high potential tendency to form genomic panhandle pseudocircle (Table 4).

\section{DISCUSSION}

In India, tospoviruses have emerged as a serious threat to vegetable crops (38) during the last 10 to 15 years. However, only a few tospovirus sequences have been reported from vegetables grown in different parts of the country $(13,17,26,31,32)$. Therefore, the present study represents a comprehensive analysis of genetic diversity of $\mathrm{N}$ gene sequences of field isolates of PBNV, WBNV, CaCV, and IYSV collected over a period of 8 years. The information expands our current knowledge on distribution of vegetable-infecting tospoviruses across the country and the information on diversity of tospoviruses offers a prelude to initiating management strategies for mitigating their negative impacts on vegetable production $(4,8,22-24)$.

In this study, the three distinct tospoviruses of the WSMoV serogroup were detected in different vegetable crops and the multiplex RT-PCR protocols described provided reliable diagnostic tools for their discrimination in single and mixed virus infections. Such a capability is critical for accurate detection of a specific virus given the high cross-reactivity of PAbs and MAbs used in this study (Table 1). In almost all previous studies $(5,9,11,12,27,28,35)$, ELISA tests were used to survey vegetables for tospoviruses and positive ELISA readings with antibodies to the $\mathrm{N}$ protein of PBNV were interpreted as PBNV infections by overlooking high cross-reactivity of polyclonal antibodies. This could be a reason why reliable information on mixed infections of PBNV and WBNV in different vegetables, the expanded host range of WBNV to tomato and chili peppers and the distribution of $\mathrm{CaCV}$ has until now been overlooked. In this context, our findings of expanded host range of WBNV and mixed infections of PBNV and WBNV will be substantially informative and offers new information that has practical importance to vegetable crop improvement against tospoviruses.

Molecular analysis of the complete S- and M-RNA segments of WBNV indicated that the coding strategy is identical to that of other tospoviruses $(6,30,37)$. Comparison of $\mathrm{N}$ protein amino acid sequences and serological relations revealed that WBNV was most closely related to PBNV in WSMoV serogroup. However, the identities of S- and M-RNA sequences with other tospoviruses within this serogroup were less than $86 \%$. It has been proposed that any tospovirus with an $\mathrm{N}$ protein sequence showing less than $90 \%$ identity with that of any other tospoviruses should be considered a distinct species (7). Therefore, based on molecular characterization of S- and M-RNA of WBNV and in conjunction with previous reports $(14,33)$, we conclude that WBNV should be confirmed as distinct species in the genus Tospovirus.

This work analyzed the genetic diversity of five tospoviruses collected over a period of 8 years and their phylogenetic analysis revealed that all the IYSV isolates studied clustered together and PBNV, WBNV, and CaCV segregated into two clades with no geographic structuring. A possible explanation for this might be that IYSV isolates were obtained only from onion and transmission specificity of IYSV by Thrips tabaci might be contributing to purifying selection. In contrast, variability among PBNV, WBNV,

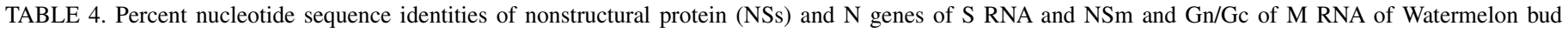
necrosis virus Jalna isolate (WBNV-Wm-Jal) with other tospoviruses

\begin{tabular}{|c|c|c|c|c|c|c|c|c|c|c|c|c|}
\hline \multirow[b]{4}{*}{ Virus $^{\mathrm{a}}$} & \multicolumn{6}{|c|}{ S RNA } & \multicolumn{6}{|c|}{ M RNA } \\
\hline & \multirow{3}{*}{$\begin{array}{c}\text { Accession } \\
\text { Number }\end{array}$} & \multicolumn{4}{|c|}{ Percent identity } & \multirow{3}{*}{$\begin{array}{l}\text { Total } \\
\text { length }\end{array}$} & \multirow{3}{*}{$\begin{array}{c}\text { Accession } \\
\text { Number }\end{array}$} & \multicolumn{4}{|c|}{ Percent identity } & \multirow{3}{*}{$\begin{array}{r}\text { Total } \\
\text { length }\end{array}$} \\
\hline & & \multicolumn{2}{|c|}{ NSs } & \multicolumn{2}{|c|}{$\mathrm{N}$} & & & \multicolumn{2}{|c|}{$\mathrm{NSm}$} & \multicolumn{2}{|c|}{$\mathrm{Gn} / \mathrm{Gc}$} & \\
\hline & & nt & aa & nt & aa & & & nt & aa & nt & aa & \\
\hline WBNV & EU249351 & 100.0 & 100.0 & 100.0 & 100.0 & 3,405 & FJ694963 & 100.0 & 100.0 & 100.0 & 100.0 & 4,794 \\
\hline PBNV-Pn & NC003619 & 80.6 & 85.6 & 79.9 & 85.1 & 3,057 & NC003620 & 80.0 & 84.3 & 76.6 & 65.3 & 4,801 \\
\hline PBNV-Mb & AY871098 & 79.9 & 84.9 & 78.9 & 85.1 & 3,057 & AY871097 & 80.1 & 84.6 & 75.9 & 67.7 & 4,815 \\
\hline WSMoV & NC003843 & 80.9 & 85.4 & 78.1 & 84.0 & 3,524 & NC003841 & 75.0 & 78.5 & 74.0 & 66.3 & 4,880 \\
\hline CaCV-India & FJ011449 & 75.9 & 80.8 & 77.6 & 80.3 & 3,105 & FJ011450 & 77.3 & 81.1 & 73.3 & 65.5 & 4,821 \\
\hline CaCV-Thi & DQ256123 & 75.9 & 80.6 & 77.2 & 80.0 & 3,477 & NC008303 & 76.3 & 82.1 & 73.4 & 65.8 & 4,823 \\
\hline TZSV & NC010489 & 63.3 & 59.0 & 64.8 & 63.3 & 3,279 & NC010490 & 69.8 & 69.9 & 66.3 & 54.9 & 4,945 \\
\hline MYSV & $\mathrm{AB} 038343$ & 54.5 & 45.2 & 62.6 & 59.1 & 3,232 & NC008307 & 62.8 & 61.7 & 61.9 & 50.6 & 4,815 \\
\hline IYSV & AF001387 & 55.0 & 49.8 & 52.5 & 42.0 & 3,105 & AF214014 & 66.6 & 64.8 & 59.5 & 46.8 & 4,838 \\
\hline TSWV & D13926 & 36.4 & 17.2 & 40.2 & 27.2 & 2,837 & NC002050 & 45.4 & 33.9 & 43.3 & 25.0 & 4,821 \\
\hline INSV & $\mathrm{NC} 003624$ & 37.5 & 17.9 & 41.6 & 25.1 & 2,992 & NC003616 & 49.0 & 35.1 & 44.9 & 24.8 & 4,972 \\
\hline GRSV & L12048 & 35.8 & 16.8 & 41.3 & 27.2 & 3,049 & ND & ND & ND & ND & ND & ND \\
\hline GRSV-NSm & ND & ND & ND & ND & ND & ND & AF213673 & 51.9 & 38.7 & ND & ND & 1,024 \\
\hline GRSV-Gn/GC & ND & ND & ND & ND & ND & ND & AY574055 & ND & ND & 43.6 & 24.6 & 3,817 \\
\hline TCSV-NSm & ND & ND & ND & ND & ND & ND & AF213674 & 51.1 & 38.7 & ND & ND & 1,024 \\
\hline TCSV-Gn/Gc & ND & ND & ND & ND & ND & ND & AY574054 & ND & ND & 43.8 & 24.6 & 3,822 \\
\hline CSNV & AF067068 & ND & ND & 46.3 & 28.3 & 783 & AF213675 & 51.6 & 37.4 & ND & ND & 1,025 \\
\hline CCSV & AY867502 & 61.6 & 60.6 & 63.4 & 65.3 & 3,172 & ND & ND & ND & ND & ND & ND \\
\hline PCFV & AF080526 & 33.4 & 14.3 & 39.2 & 18.1 & 2,833 & ND & ND & ND & ND & ND & ND \\
\hline PYSV & AF013994 & 32.6 & 11.2 & 36.0 & 17.2 & 2,970 & ND & ND & ND & ND & ND & ND \\
\hline TYFRV & DQ462163 & 57.8 & 52.1 & 53.6 & 42.4 & 3,006 & ND & ND & ND & ND & ND & ND \\
\hline
\end{tabular}

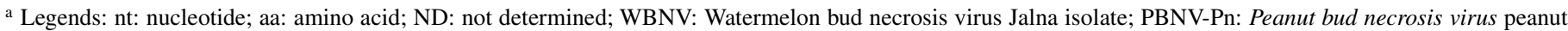
isolate; PBNV-Mb: Peanut bud necrosis virus mungbean isolate; WSMoV: Watermelon silver mottle virus; MYSV: Melon yellow spot virus; CaCV: Capsicum chlorosis virus; CCSV: Callalilly chlorotic spot virus; IYSV: Iris yellow spot virus; TSWV: Tomato spotted wilt virus; INSV: Impatiens necrotic spot virus; GRSV: Groundnut ring spot virus; PCFV: Peanut chlorotic fan spot virus; PYSV: Peanut yellow spot virus; TZSV: Tomato zonate spot virus; TCSV: Tomato chlorotic spot virus; CSNV: Chrysanthemum stem necrosis virus; and TYFRV: Tomato yellow fruit ring virus. 
and $\mathrm{CaCV}$ could be due to their origin from different host species, although they all may be transmissible by the same vector $T$. palmi. The lack of geographic structuring or host specificity of different clades would suggest polyphyletic nature of virus variants that are circulating in vegetable cropping systems across the country possibly due to movement of thrips vector. However, further studies are required to understand the geographic distribution of tospoviruses and their variants and transmission efficiency of the thrips vectors in India.

\section{ACKNOWLEDGMENTS}

The first and second authors contributed equally to this study and the third author characterized $36 \mathrm{PBNV}$ isolates during doctoral degree program with funding from Mahyco. The fifth author has produced PAb and MAb antisera against WSMoV. Part of the reconnaissance studies (2006 to 2007) and WBNV S-RNA characterization was supported by the Agriculture Office within the Bureau for Economic Growth, Agriculture, and Trade (EGAT) of the U.S. Agency for International Development (USAID), under the terms of the Integrated Pest Management Collaborative Research Support Program (IPM CRSP) co-operative agreement award No. EPP-A-00-04-00016-00 to R. A. Naidu. The opinions expressed herein are those of the authors and do not necessarily reflect the views of the USAID. PPNS 0539 Department of Plant Pathology, College of Agricultural, Human, and Natural Resource Sciences Agricultural Research Center Project No. WNPO 0616, Washington State University, Pullman 99164-6240. We thank vegetable growers and farmers for giving us access to fields and providing information on prevalence of diseases in crops during our field visits in India. We acknowledge R. Anandalakshmi, Mahyco Research Center, and H. R. Pappu, Washington State University, for critical review of the manuscript.

\section{LITERATURE CITED}

1. Bhanupriya, M., Srinivasulu, P., Usha, B. Z., and Ravi, K. S. 2005. Natural occurrence and genetic diversity of Tospovirus isolates from India. Pages 2-3 in: VIII International Symposium on Thysanoptera and Tospoviruses. D. Ullman, J. Moyer, R. Goldbach, and G. Moritz, eds. J. Insect Sci. 7:28

2. Chen, K., Xu, Z., Yan, L., and Wang, G. 2007. Characterization of a new strain of Capsicum chlorosis virus from peanut (Arachis hypogaea L.) in China. J. Phytopathol. 155:178-181.

3. Chen, T.-C., Huang, C.-W., Kuo, Y.-W., Liu, F.-L., Hsuan Yuan, C.-H., Hsu, H.-T., and Yeh, S.-D. 2006. Identification of common epitopes on a conserved region of NSs proteins among tospoviruses of Watermelon silver mottle virus serogroup. Phytopathology 96:1296-1304.

4. Chiemsombat, P., Gajanandana, O., Warin, N., Hongprayoon, R., Bhunchoth, A., and Pongsapich, P. 2008. Biological and molecular characterization of tospoviruses in Thailand. Arch. Virol. 153: 571-577.

5. Cortes, I., Livierators, I. C., Derks, A., Peters, D., and Kormelink, R. 1998. Molecular and serological characterization of Iris yellow spot virus, a new and distinct tospovirus species. Phytopathology 88:1276-1282.

6. de Haan, P., Wagemakers, L., Peters, D., and Goldbach, R. 1990. The S RNA segment of Tomato spotted wilt virus has an ambisense character. J. Gen. Virol. 71:1001-1007.

7. Fauquet, C. M., Mayo, M. A., Maniloff, J., Desselberger, U., and Ball, L. A. 2005. Virus Taxonomy 8th Report of the International Committee on Taxonomy of Viruses. Elsevier Academic Press, San Diego, CA.

8. García, A. F., Fraile, A., and Malpica, J. M. 2001. Variability and genetic structure of plant virus populations. Annu. Rev. Phytopathol. 39:157-186.

9. Gera, A. J., Cohen, R. S., and Raccah, B. 1998. Iris yellow spot tospovirus detected in onion (Allium cepa) in Israel. Plant Dis. 82:127.

10. Ghanekar, A. M., Reddy, D. V. R., Iizuka, N., Amin, P. W., and Gibbons, R. W. 1979. Bud necrosis of groundnut (Arachis hypogaea) in India caused by tomato spotted wilt virus. Ann. Appl. Biol. 93:173-179.

11. Hemalatha, V., Pradnya, G., Anjali, A. K., Reddy, M. K., and Savithri, H. S. 2008. Monoclonal antibodies to the recombinant nucleocapsid protein of a Ground bud necrosis virus infecting tomato in Karnataka and their use in profiling the epitopes of Indian tospovirus isolates. Curr. Sci. 95:952-957.

12. Hsu, H. T., Ueng, P. P., Chu, F. H., Ye, Z., and Yeh, S. D. 2000. Serological and molecular characterization of high temperature-recovered virus belonging to tospovirus serogroup IV. J. Gen. Plant Pathol. 66:167175.
13. Jain, R. K., Bag, S., Umamaheswaran, K., and Mandal, B. 2007. Natural infection by tospoviruses of cucurbitaceous and fabaceous vegetable crops in India. J. Phytopathol. 155:22-25.

14. Jain, R. K., Pappu, H. R., Pappu, S. S., Krishnareddy, M., and Vani, A. 1998. Watermelon bud necrosis tospovirus from India is a distinct virus species belonging to serogroup IV. Arch. Virol. 43:1637-1644.

15. Jones, R. A. C., and Sharman, M. 2005. Capsicum chlorosis virus infecting Capsicum аппиит in East Kimberley region of Western Australia. Australas. Plant Pathol. 34:397-399.

16. Knierim, D., Blawid, R., and Maiss, E. 2006. The complete nucleotide sequence of a Capsicum chlorosis virus isolate from Lycopersicum esculentum in Thailand. Arch. Virol. 151:1761-1782.

17. Krishnareddy, M., Rani, R. U., Kumar, A., Reddy, K. M., and Pappu, H. R. 2008. First report of Capsicum chlorosis virus (genus Tospovirus) infecting chili pepper (Capsicum апnиum) in India. Plant Dis. 92:1469.

18. Kunkalikar, S., Sudarsana, P., Rajagopalan, P., Zehr, U. B., Naidu, R. A., and Ravi, K. S. 2007. First report of Capsicum chlorosis virus in tomato in India. Plant Health Progress doi: 10.1094/PHP-2007-1204-01-BR.

19. Kunkalikar, S. R., Sudarsana, P., Rajagopalan, P., Zehr, U. B., and Ravi, K. S. 2010. Biological and molecular characterization of Capsicum chlorosis virus infecting chili and tomato in India. Arch. Virol. 155:10471057.

20. Mandal, B., Jain, R. K., Chaudhary, V., and Varma, A. 2003. First report of natural infection of Luffa acutangula by Watermelon bud necrosis virus in India. Plant Dis. 87:598.

21. McMichael, L. A., Persley, D. M., and Thomas, J. E. 2002. A new tospovirus serogroup-IV species infecting capsicum and tomato in Queensland, Australia. Australas. Plant Pathol. 31:231-239.

22. Pappu, H. R. 2008. Tomato spotted wilt virus (Bunyaviridae). Pages $133-$ 138 in: Encyclopedia of Virology. Vol. 5, 3rd ed. B. W. J. Mahy and M. H. V. Van Regenmortel, eds. Elsevier Ltd., Oxford, UK.

23. Pappu, H. R., du Toit, L. J., Schwartz, H. F., and Mohan, K. 2006. Sequence diversity of the nucleoprotein gene of Iris yellow spot virus (genus Tospovirus, family Bunyaviridae) isolates from the western region of the United States. Arch. Virol. 151:1015-1023.

24. Pappu, H. R., Jones, R. A. C., and Jain, R. K. 2009. Global status of tospovirus epidemics in diverse cropping systems: Successes achieved and challenges ahead. Virus Res. 141:219-236.

25. Ravi, K. S., Kitkaru, A. S., and Winter, S. 2006. Iris yellow spot virus in onions: A new tospovirus record from India. Plant Pathol. 55:288.

26. Ravi, K. S., Kunkalikar, S., Bhanupriya, M., Sudarsana, P., Rajagopalan, P., Usha, B. Z., and Naidu, R. A. 2007. Current status of tospovirus infecting vegetable crops in India. In: Abstracts of 10th International Plant Virus Epidemiology Symposium: Controlling Epidemics of Emerging and Established Plant Virus Diseases-The Way Forward. ICRISAT, Hyderabad, India.

27. Reddy, D. V. R., Ratna, A. S., Sudarshana, M. R., Poul, F., and Kiran Kumar, I. 1992. Serological relationships and purification of Peanut bud necrosis virus, a tospovirus occurring in peanut (Arachis hypogaea L.) in India. Ann. Appl. Biol. 120:279-286.

28. Reddy, D. V. R., Satyanarayana, T., Dwivedi, S. L., Ratna, A. S., Buiel, A. A. M., Rao, G. V. R., Nigam, S. N., Naidu, R. A., Hsu, H. T., and Demski, J. W. 1996. Diagnosis and resistance breeding of Peanut bud necrosis virus. Acta Hortic. 431:411-414.

29. Sambrook, J., Fritsch, E. F., and Maniatis, T. 1989. Molecular Cloning: A Laboratory Manual. 2nd eds. Cold Spring Harbor Laboratory, Cold Spring Harbor, NY.

30. Saritha, R. K., and Jain, R. K. 2007. Nucleotide sequence of the S and M RNA segments of a Groundnut bud necrosis virus isolate from Vigna radiata in India. Arch. Virol. 152:1195-1200.

31. Satyanarayana, T., Gowda, S., Reddy, L. K., Mitchell, S. E., Dawson, W. O., and Reddy, D. V. R. 1998. Peanut yellow spot virus is a member of a new serogroup of Tospovirus genus based on small (S) RNA sequence and organization. Arch. Virol. 143:353-364.

32. Satyanarayana, T., Mitchell, S. E., Reddy, D. V. R., Brown, S., Kresovich, S., Jarret, R., Naidu, R. A., and Demski, J. W. 1996. Peanut bud necrosis tospovirus S RNA: Complete nt sequence, genome organization and homology to other tospoviruses. Arch. Virol. 141:85-98.

33. Singh, S. J., and Krishna Reddy, M. 1996. Watermelon bud necrosis virus; A new tospovirus disease. Acta Hort. 431:68-77.

34. Tamura, K., Dudley, J., Nei, M., and Kumar, S. 2007. MEGA4: Molecular Evolutionary Genetics Analysis (MEGA) software version 4.0. Mol. Biol. Evol. 24:1596-1599.

35. Thakur, M. P., Reddy, D. V. R., Reddy, A. S., Ratna, A. S., Al-Nasiri, M., and Agrawal, K. C. 1996. Identification of bud blight of soybean (Glycine $\max$ L. Merr.) through ELISA and infectivity assay. Ind. J. Virol. 12:7982.

36. Thomas, L., German, D. E., Ullman, J., and Moyer, W. 1992. Tospoviruses: Diagnosis, molecular biology, phylogeny, and vector relationships. Annu. Rev. Phytopathol. 30:315-348. 
37. van Knippenberg, I., Goldbach, R., and Kormelink, R. 2005. Tomato spotted wilt virus $\mathrm{S}$-segment mRNAs have overlapping $3^{\prime}$ ends containing a predicted stem-loop structure and conserved sequence motif. Virus Res. 110:125-131.

38. Varma, A. 2007. Emergence and reemergence of plant viruses in India: impact and management options. In: Abstracts of 10th International Plant
Virus Epidemiology Symposium: Controlling Epidemics of Emerging and Established Plant Virus Diseases-The Way Forward. ICRISAT, Hyderabad, India.

39. Yeh, S. D., Sun, I. J., Ho, H. M., and Chang, T. F. 1996. Molecular cloning and sequence analysis of the S RNA of Watermelon silver mottle virus. Acta. Hort. 431:244-259. 